\title{
開口噴出気流温度の相似則としての無次元温度の適用性 APPLICABILITY OF NONDIMENSIONAL TEMPERASURE FOR SCALING
THE TEMPERATURES OF WINDOW JET PLUME
}

\author{
山口純一*, 岩井裕子**, 田中哮義***, 原田和典**** \\ 大宮喜文****; 若松孝旺****** \\ Jun-ichi YAMAGUCHI, Yuko IWAI, Takeyoshi TANAKA, \\ Kazunori HARADA, Yoshihumi OMIYA and Takao WAKAMATSU
}

In order to develop a means to assess the effectiveness of some ciesign elements for preventing upper floor fire spread, such as window geometry and arrangement of eaves above windows, possibility of scaling of window jet plume temperature distribution by means of a nondimensional temperature was explored. Experiments were conducted using two geometrically similar setups having different sizes to investigate the applicability of the nondimensional temperature to various conditions.

It was found that the nondimensoinal temperature is independent of size and fire temperature but is uniquely determined only by geometrical conditions, that is, it is possible to predict real scale window jet plume temperatures based on the results of reduced scale experiments.

Keywords: Upper floor firc spread, Gcometry, Windew ict plume, similarity, Nondimensional temperature 上階延焼、形状、開口噴出気流、相似、無次元温度

1.はじめに

建物の一室で生じた火災が拡大して、空ガラスが破れ、火炎・熱 気流が噴出すると、これらは上階の窓ガラスを破って上階の空間に 侵入し、上階延焼をもたらす危険を生じる。上階延焼の危険性や、 種々の防止対策の効果を評価するためには、先ずこの空からの噴出 熱気流の性状の把握が必要となる。

火災室開口からの熱気流の性状に関する研究は横井により最も采 統的に行われ、火炎・熱気流の気流軸（トラジェクトリ）上の温度 分布を予測する無次元パラメータが提示され、それによる模型実験 と実大火災実験との相似性も確認されている。"しかし、上階の空 ガラスの破損に直接つながるのは、気流軸に沿っての温度よりも、 むしろ空が直接暴露される空付近の温度である。噴出熱気流の温度 は気流軸上に添って最も高いので、もし空ガラスの破損を気流軸上 の温度に基づいて評価すると、安全側ではあるが過唾な対策を強い られる恐れがある。また、開口の形状及びバルコニーの有無や寸法 等は気流軸の形状に影響を与え、従って空付近の温度にも影響する が、これらの様々な因子の上階延焼に及ほす影響が評価できない。 一般に、空開口の形状やバルコニー等上階延焼防止のための設計
的対策となり得る因子の条件は建物毎に異なるので、これらが噴出 文流の性状に及ぼす影響は、各々の条件毎に実験的に検証するのが 望志しいが、実大実験によって調べるのには費用、労力ともに過重 である。しかし、開口噴出気流に関する適切な相似則が得られれ ば、模型実験の結果を用いてそれらの影響を評洒することが可能に なり、実験的手法に現実性が出てくる。

そこで、本研究では、上階の空近傍の温度を含む開口噴出気流の 温度分布一般に関する相似則を与えると考えられる無次元温度を考 え、種冬の条件に対するその適用可能性を実験的に調べた。

\section{2. 瑟次元温度}

横井は、嘖出気流のトラジェクトリに沿った温度分布が、次式で

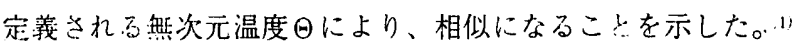

$$
\Theta=\Delta T_{0} r_{0}{ }^{5 / 3} /\left(T_{\infty} \dot{Q}_{D}{ }^{2} / c_{p}{ }^{2} \rho^{2} g\right)^{1 / 3}
$$

ここで、 $\Delta T_{0}$ は気流軸上の任意の位置における開口噴出気流の上帠 温度、 $r_{0}$ は開口噴流の等価半径、 $T_{c x}$ は外気温度、 $\dot{Q}_{D}$ は開口噴出気流 の持ち出す熱量、 $c_{p}$ は気体の定圧比熱、 $\rho$ は気流軸上の任意の位置

Obayashi Corporation, M. Eng.

* 株式会社大林組 工修

** 東京理科大学理工学部建築学科 研究補助員

*** 京都大学防災研究所 教授・工博

****建設省建築研究所防煙研究室 主任研究員 · 工博

***** 建設省建築研究所防火材料研究室 研究員. 工博

******* 東京理科大学理工学部建築学科 教授.工博
Assistant Investigator, Dept. of Architecture, Faculty of Sci. and Tech., Sci. Univ. of Tokyo

Prof., DPRI, Kyoto University, Dr. Eng.

Smoke Control Div., Building Research Institute, MOC., Dr. Eng. Fire Preventive Materials Div., Building Research Institute, MOC., Dr. Eng. Prof., Dept. of Architecture, Faculty of Sci. and Tech., Science Univ. of Tokyo, Dr. Eng. 
における気流密度、gは重力加速度である。

さて式(1)は、現在、火災研究分野で広く用いられている無次元 熱量 $\dot{Q}^{*}$ を用いると下式のように表現できる。

$$
\Theta=\frac{\frac{\Delta T_{0}}{T_{\infty}}}{\dot{Q}_{D}^{* 2 / 3}\left(\frac{T_{0}}{T_{\infty}}\right)^{2 / 3}}
$$

ただし、 $T_{0}$ は氛流軸上の任意の位置における開口噴出気流の温度で あり、 $\dot{Q}_{D}^{*}$ は下式で定義される開口噴出気流の無次元熱量である。

$$
\dot{Q}_{D}^{*}=\frac{\dot{Q}_{D}}{\rho_{\infty} c_{p} T_{\infty} \sqrt{g} \overline{r_{i}, r_{0}^{2}}}
$$

ここに、 $\rho_{\infty}$ は周囲空気密度である。

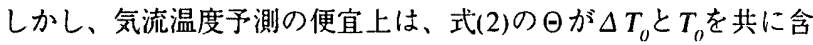
むのは不都合であるため、本研究では横井の無次元温度を変形した 式(2)を幾分緩和し、式(2)における $\left(T_{0} / T_{\infty}\right)^{2 / 3}$ を無視する。また、無 次元温度 $\Theta$ を気流軸上の上昇温度 $\Delta T_{1}$ のみでなく、任意の位置 $(x, y)$ の上昇温度 $\Delta T(x, y)$ に掋張して

$$
\Theta \equiv \frac{\frac{\Delta T(x, y)}{T_{\infty}}}{\dot{Q}_{D}^{* 2 / 3}}
$$

\section{のように定義する。}

更に幾何学的相似が保たれている条件下の議論である限り、代表 寸法は必ずしも等価半径 $r_{0}$ とする必要はないので、簡単のため代表 寸法を開口高さHとし、伴って $\dot{Q}_{D}^{*}$ を

$$
\dot{Q}_{D}^{*} \equiv \frac{\dot{Q}_{D}}{\rho_{\infty} c_{p} T_{\infty} \sqrt{g H} H^{2}}
$$

と定義する。因みに、式(4)及び(5)は、熱量や代表寸法は異なって いるが、形態上は火源上の火災プルームの温度に対する相似を与え
る式と同じである。

横拦によれば、気流軸上の温度に関する式(1)の)無次元温度 $\Theta$ は 寸法や温度に関係なく、開口の幾何学的形状のみに依存する量であ る。父流軸上の温度に関してこの関係があるならば、気流軸以外の 部分でも一般的に同様の関係があると考えるのは自然であるう。 こでひ目的は、上階のガラス空近傍を含む開口噴出気流中の任意の 位置の温度に関して新たに考えた式(4)の無次元温度が、実際の建 築物で見られる開口や庇の形状的条件の下で、やはり幾何学的形状 のみの関数になるか否かを実験的に調べることである。

\section{3. 実験摡要}

本実験では異なるスケール間の相似、性を検証するため、表にに示 すような3倍のスケール差のある2つの立方体の火災区画模型を使用 し実験を行った。なお、両者は開口及び庇の形状、設置位置を含め 幾何学的に相似である。ただし、区画壁材は同一の厚さであり相似 ではない。なお、以下では、模型|を使用して行った実験を小規模 実験、模型2を使用して行った実験を中規模実験と呼ぶ。

表1 使用火災区画模型概要

\begin{tabular}{cc||cc}
\hline 模型 & (規模) & 形状 & 内法 $(\mathrm{m})$ \\
\hline \hline 1 & (小) & 立方体 & 0.5 \\
\hline 2 & (中) & 立方体 & 1.5 \\
\hline
\end{tabular}

\section{1 寒験装罪}

本実験で使用した実験模型と温度測定位置を図1に示す。 区画模型は、内法一辺 $1.5(\mathrm{~m})$ の立方体（中規模模型）と、内法- 辺0.5 $(\mathrm{m})$ の立方体（小規模模型）の2つを使用し、何狄も厚さ12(mm) のバーシイト板で作成した。なお、両者は当然相似であるので、図 1でに一辺り長さを10hとしている。ここで、中規模模型ではん $=0.15$ $(\mathrm{m})$ 、小規模模型では $\mathrm{h}=0.05(\mathrm{~m})$ である。

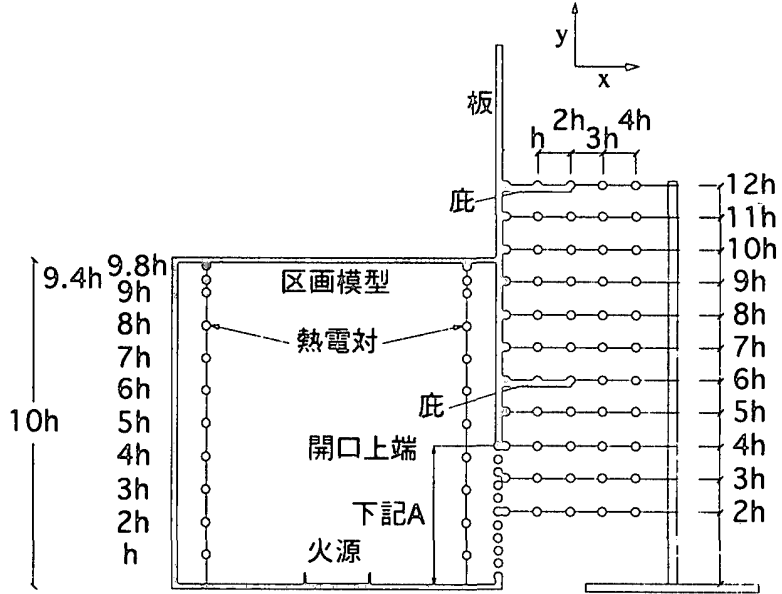

(a) 断面図
単位 $m$

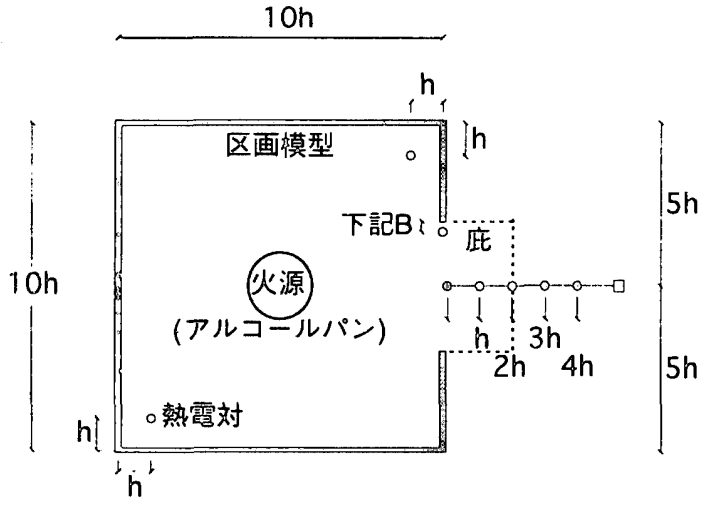

(b) 平面図

中規慔害験 $h=0.15(m)$ 小規模害験 $h=0.05(m)$

\footnotetext{
A：熱電対設置間隔、中規模実験は $0.03(\mathrm{~m})$ 、小規模実験は $0.015(\mathrm{~m})$

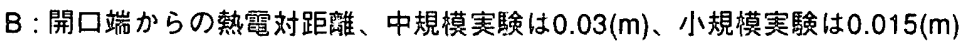
図1 实験区画模型 
区画側壁には開口を設置し、別に用意した開ロパネルを取り付け ることにより開口の形状及び寸法を変化できるようにした。

庇は、開口高さ $\mathrm{H}$ 基準とし、開口上端から $\mathrm{H} / 2$ 上方と、 $2 \mathrm{H}$ 上方 の2ヶ所に設置した。ただ、図にに示した庇の設置位置は開口高さ $\mathrm{H}$ 怆とした時の例である。

火源としてはアルコールパンを用い、模型室内の底面中央部に設 置した。

\section{2 温度測定位置}

本実験では、開口噴出気流の温度、区画内温度及び開口部温度を 図1に示す位置で測定した。なお、小、中規模実験における噴出気 流温度及び区画内温度の測定位置は幾何学的に相似の位置である。

開口噴出気流の温度は区画模型の中心軸上で測定し、開口下端か $52 \mathrm{~h}(\mathrm{~m})$ （中規模実験 $\mathrm{h}=0.15$ 、小規模実験 $\mathrm{h}=0.05$ ）上方の位置を基 準として水平方向に $\mathrm{h}(\mathrm{m})$ 間隔で5点、垂直方向に $\mathrm{h}(\mathrm{m})$ 間隔で 11 点測 定した。

区画内空気温度は、図1中に示す平面上の2ヶ所の点で、それぞれ 垂直方向に11点測定した。

開口部における温度測定のための熱電対は、中規模実験において は開口左端から $30(\mathrm{~mm})$ の位置で開口下端から垂直方向に30( $\mathrm{mm})$ 間隔 で熱電対を設置し、小規模実験においては開口左端から $15(\mathrm{~mm})$ の位 置で開口下端から垂直方向に15(mm)間隔で設置した。なお、熟電対 の開口左端からの位置は、温度が開口端部の縮流の影響を受けない ことを確認して定めた。3i

\section{3 実験条件}

小規模及び中規模実験における実験条件を、それぞれ表2及び3に 示す。

開口形状は、縦長（幅：高さ=1：2）、正方形（幅：高さ=2：

2)、及び横長（幅：高さ $=2: 1$ ）の3種類とた。

庇を設置する場合は、奥行きを開口高さHの1/2とし、幅を開口幅 （以下、短い庇）及び区画幅（以下、長い庇）の2通りに変化させ た条件と、庇を設置しない条件（以下、庇無し）の3種類とした。

火源はメタノールを然料として用い、アルコールパンの径を変化 させることにより開口部における噴出気流の熱量を変化させた。ま た、パン径は換気支配となって噴出火炎の発生することがないよう な大きさの範囲内で設定した。

実験は、開口、庇及びパン径の条件全ての組み合わせに対して 行った。

表2 小規模実験

\begin{tabular}{|c|c|c||c|c||c|}
\hline \multicolumn{3}{|c||}{ 開口 } & \multicolumn{2}{|c|}{ 庇の形状 } & パン径 \\
\hline 形状 & 幅 $\mathrm{B}(\mathrm{m})$ & 高さ $\mathrm{H}(\mathrm{m})$ & 奥行き $(\mathrm{m})$ & 幅 $(\mathrm{m})$ & $(\mathrm{m})$ \\
\hline \hline 縦長 & 0.1 & 0.2 & \multicolumn{2}{|c||}{ なし } & 0.10 \\
\hline 正方形 & 0.2 & 0.2 & $\mathrm{H} / 2$ & 開口幅 & 0.15 \\
\hline 横長 & 0.2 & 0.1 & $\mathrm{H} / 2$ & 0.5 & 0.20 \\
\hline
\end{tabular}

表3 中規模実験

\begin{tabular}{|c|c|c|c|c|c|}
\hline \multicolumn{3}{|c|}{ 開口 } & \multicolumn{2}{|c|}{ 庇の形状 } & \multirow{2}{*}{$\begin{array}{c}\text { パン径 } \\
\text { (m) }\end{array}$} \\
\hline 形状 & 幅B(m) & 高さ $\mathrm{H}(\mathrm{m})$ & 奥行き(m) & 幅(m) & \\
\hline 絴長 & 0.3 & $\overline{0.6}$ & \multicolumn{2}{|c|}{ なし } & 0.3 \\
\hline 正方形 & 0.6 & 0.6 & $\mathrm{H} / 2$ & 開口幅 & 0.4 \\
\hline $\begin{array}{l}\text { 横長 } \\
\end{array}$ & 0.6 & 0.3 & $\mathrm{H} / 2$ & 1.5 & 0.6 \\
\hline
\end{tabular}

\section{4 測定方法}

実験は火源に着火後約15分待ち、火災区画内温度の定常が確認さ れた後計測を開始した。測定は2秒間隔で2分間計測した。また、後 に示す実験結果はこの2分間のデータの平均値を用いた。

\section{4. 実験結果及び考察}

\section{1 開口喷出気流温度と開口噴流熱量及び空間規模の関係}

図2は、小規模及び中規模実験で得られた実騃結果の中で、開口 形状が長方形（B：H=1：2）、庇無しの条件における開口噴出気流 の等温度分布 $\Delta T(x, y)$ を火源のパン径別に示したものである。な お、図中にはパン径と共に開口噴出気流の熱量 $\dot{Q}_{l}$ も同時に示して いるが、これは、火源規模を表すパン径よりもこの開口噴出気流の 熱量 $\dot{Q}_{D}$ の方が開口噴出気流温度に直接的に影響を与える物理量で あるからである。なお、開口部における噴出気流の熱量 $\dot{Q}_{D}$ は、開 口から火炎が発生していないことから、下式より算出した。

$$
\dot{Q}_{i)}=c_{p} m_{D} \Delta \bar{T}_{D}
$$

ここで、 $\Delta \widetilde{T}_{D}$ は開口噴出気流の平均上昇温度であり、中性带から開 口上端までの開口噴出気流温度の平均值を用いた。なお、中性帯高 さは開口部における噴出気流の温度分布より $\mathrm{N} \%$ 法2)を用いて算定 し、N值は10とした。 ${ }^{31}$ また、 $m_{D}$ は開口部における噴出気流の質量 流量であり、下式より算出した。

$$
m_{D}=\frac{2}{3} \alpha B\left\{2 g \rho_{S}\left(\rho_{\infty}-\rho_{S}\right)\right\}^{1 / 2}\left(H-Z_{n}\right)^{3 / 2}
$$

ここで、 $\alpha$ は流量係数、Bは開口幅、gは重力加速度、 $\rho_{s}$ 及び $\rho_{x}$ は それぞ狆区画内空気密度及び周囲空気密度、Hは開口高さ、 $Z_{n}$ は中 性带高さである。な㧍、流量係数 $\alpha$ は開口噴流の流量測定の結果 3 に基づき0.52る使用し、 $\rho_{\mathrm{s}}$ は中性帯高さから開口上端高さにおうりる 区画内温度の平均値より算出した。また、横軸は開口からの距離 $(\mathrm{m}) 、$ 縦軸は高さ $(\mathrm{m})$ である。等温線の間谝は $20(\mathrm{~K})$ であり、色の濃 いほど温度が高いことを示している。

図2によれば、開口噴出気流の等温度分布の形状は開口噴出気流 の熱量 $\dot{Q}_{D}$ の大小に関わらず似通っている。しかし、噴出気流温度 は小規模、中規模実験のそれぞれにおいて、開口噴出気流の熱量 $\dot{Q}_{D}$ の違いにより当然異なっている。

図3はそれぞれ、図2に示した実験結果を式(4)により無次元化し た無次元温度を相似の位置に对する空間分布 $\Theta(\xi, \eta) て ゙$ 示したもの

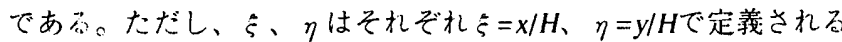
無次元位置心ある。また、無次元温度の等温線の間隔は0.5(-)であ る。

これより、図2においては小規模、中規模実験共に開口噴出気流 の温度分布は熱量 $\dot{Q}_{D}$ の変化に伴い大きく変化していたが、図3の無 次元温度分布は開口噴流の熱量 $\dot{Q}_{D}$ に関わらず互いに良く一致して いることがわかる。また、小規模と中規模のスケールの違う空間に おける温度分布を比較しても、若干の差異は見られるが、大差がな いといえる。若干の差異は、区画壁の厚さが小、中規模模型で等し く、相似になっていないこと、及び開口噴流の熱量の算定誤差によ ク生ずると思われる。これより、式(4)で定義される無次元温度 $\Theta$ の分枋は開口の法や噴出気流温度に拘わらず殆ど一定になると言 

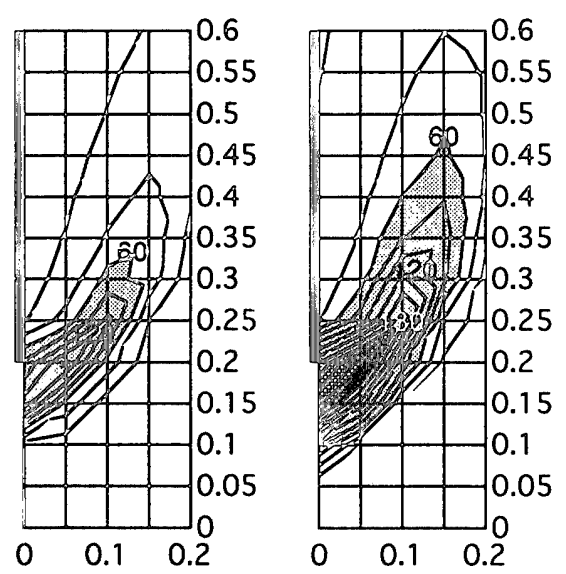

(a) $\mathrm{Q}_{\mathrm{D}}=0.4(\mathrm{~kW})$ パン径0.1(m)

(b) $Q_{0}=1.0(\mathrm{~kW})$ パン径0.15(m)

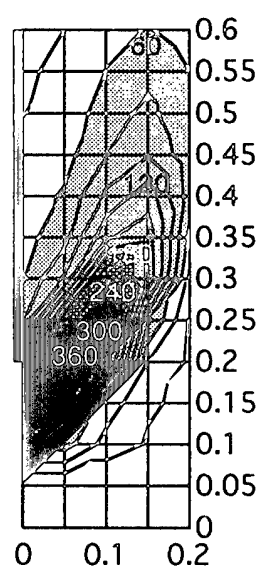

開口形状 $(0.1(B) \times 0.2(H)(m))$ 。訨無し 小規㷬实験
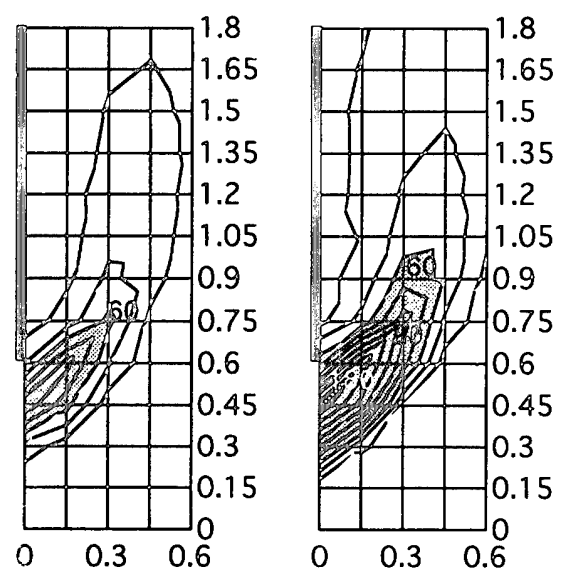

(e) $Q_{D}=12.7(\mathrm{~kW})$ パン径 $0.4(\mathrm{~m})$

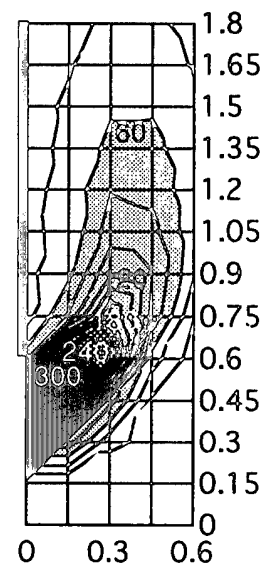

(i) $\mathrm{Q}_{\mathrm{D}}=26.7(\mathrm{~kW})$ パン径0.6(m) パン径0.3(m)

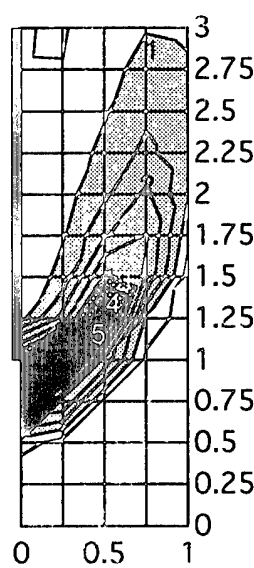

(c) $\mathrm{Q}_{\mathrm{D}}=2.2(\mathrm{~kW})$ パン径0.2(m)

開口形状 $(0.3(\mathrm{~B}) \times 0.6(\mathrm{H})(\mathrm{m}))$ ・庇無し

中規模実験

图2 開口啫出雒流温度分布 (等温線：20(K)間隔）

える。

4.2 開口喷出氞流温度と開口形状の関係

（1）庇を設罚しない場合

図4は、小規模及び中規模実験の庇を設置しない条件に扔ける開 口噴出気流の等温度分布 $\Delta T(x, y)$ を開口形状別に示した一例であ る。ただし、図4では小、中規模実験で温度差が最も大きくなり、 従って無次元温度分布が最も一致しづらいと考えられる条件、すな わち、小規模実験は火災区画内温度が最も高くなるパン径 $0.2(\mathrm{~m})$ 、 中規模実験は温度が最も低くなるパン径 $0.3(\mathrm{~m})$ の実験データの例を 比較した。

既に横井により明らかにされているように、絴長開口(a)、(d)の 噴出気流は外壁から離九て上昇するのに対し、正方形開口(b)、(e)で は外壁側に近寄り、更に横長開口(c)、(f)では外壁に沿って上昇し

\section{(a) $Q_{0}=0.4(\mathrm{~kW})$ パン径0.1(m)}

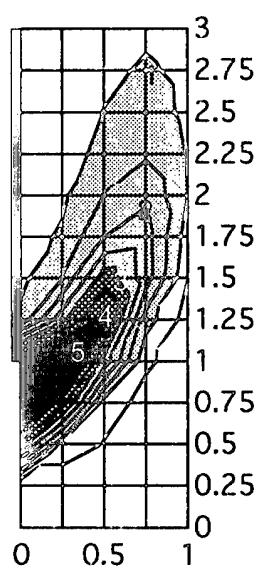

開口形状 $(0.1(B) \times 0.2(H)(m))$ 。庇無し 小規䄑实験

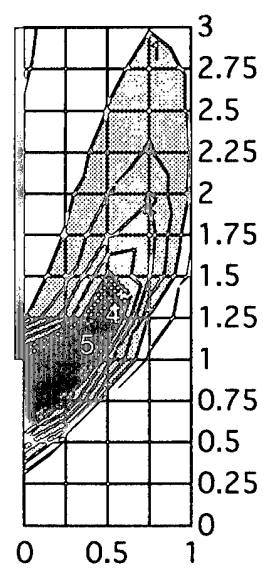
(c) $Q_{D}=2.2(\mathrm{~kW})$ パン径0.2(m)
(b) $Q_{0}=1.0(\mathrm{~kW})$
パン径0.15(m)

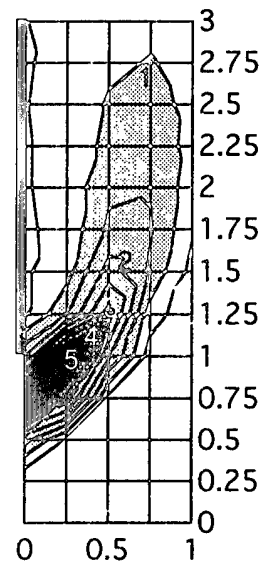

(d) $Q_{0}=5.6(\mathrm{~kW})$ バン径0.3(m)

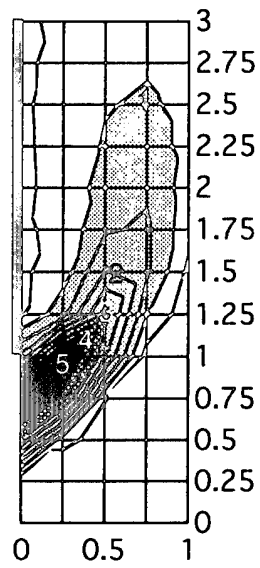

(e) $Q_{D}=12.7(\mathrm{~kW})$ パン径0.4(m)

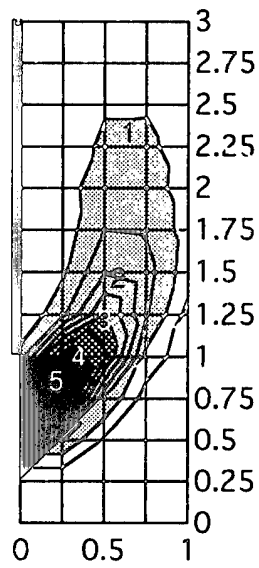

(f) $Q_{D}=26.7(\mathrm{~kW})$ パン径0.6(m)
開口形状 $(0.3(B) \times 0.6(\mathrm{H})(\mathrm{m}))$ 。訨無し 中規㷬菨験

图1 開口啐出氞流無次元温度分布（等温線：0.5(-)間隔）

ている。また、開口形状が同一である場合の噴出気流の形状は小規 模実験、中規模実験で穎似している。

図5はそれぞれ、図4に示した実験結果を式(4)により無次元化し た無次元温度の空間分布 $\Theta(\xi, \eta) て ゙$ 示したものである。

図4に示す例では、小規模実験では開口噴出気流の温度は一般に高 く、最も高い部分は約 $400{ }^{\circ} \mathrm{C}$ にで達しているのに対し、中規模実験 では開口噴出気流の温度は一般に低く、最も高い部分でも $100{ }^{\circ} \mathrm{C}$ 程 度となり、双方の開口噴出気流温度には大きな差が生じている。し かし、図5に示されるように、無次元温度に変換すると何れの開形 状に妨いても小規模と中規模実験における無次元温度は互いに良く 一致している。よって、開口噴出気流の無次元温度 外の白意心位置に掞いても温度、寸法によらす、開口の幾何学的形 状の双に依疜すると言える。 


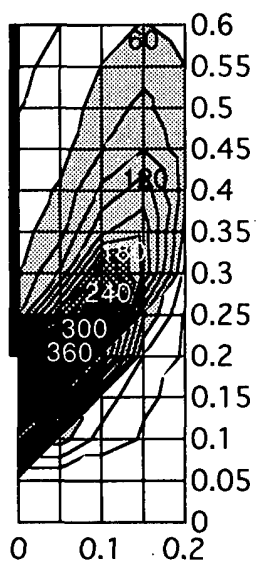

(a) 縰長開口

$0.1(\mathrm{~B}) \times 0.2(\mathrm{H})(\mathrm{m})$

$Q_{D}=2.2(\mathrm{~kW})$

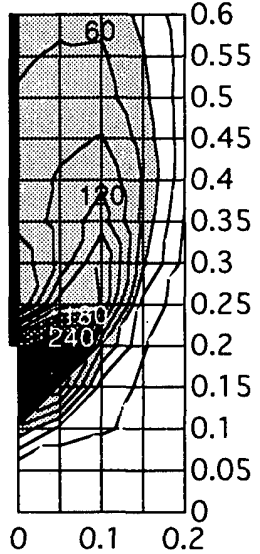

(b) 正方形開口

$0.2(\mathrm{~B}) \times 0.2(\mathrm{H})(\mathrm{m})$ $\mathrm{Q}_{\mathrm{D}}=2.3(\mathrm{~kW})$

パン径 $(0.2(\mathrm{~m}))$ ・庇無し 小規模実験

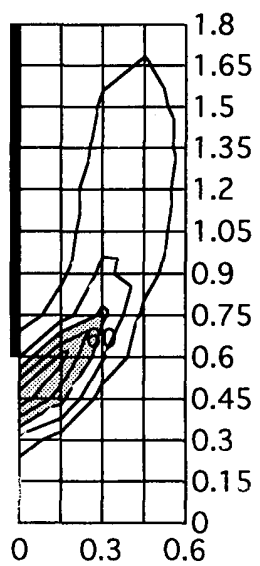

(d) 綎長開口 $0.3(\mathrm{~B}) \times 0.6(\mathrm{H})(\mathrm{m})$ $Q_{D}=5.6(\mathrm{~kW})$

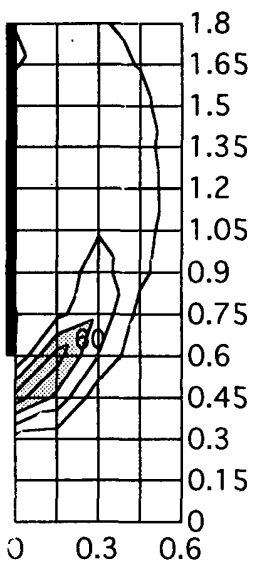

(e) 正方形開口 $0.6(\mathrm{~B}) \times 0.6(\mathrm{H})(\mathrm{m})$ $Q_{D}=4.9(\mathrm{~kW})$ パン径 $(0.3(\mathrm{~m}))$ ・庇無し 中規模実験

図4開口噴出気流温度分布（等温線：20(K)間隔）

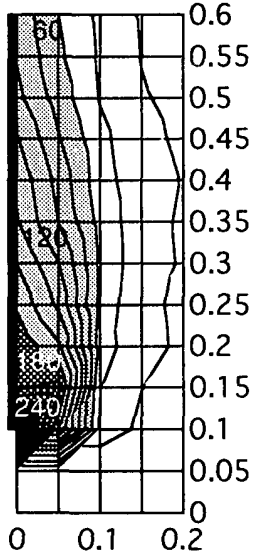

(c) 横長開口 $0.2(\mathrm{~B}) \times 0.1(\mathrm{H})(\mathrm{m})$ $Q_{D}=1.0(\mathrm{~kW})$

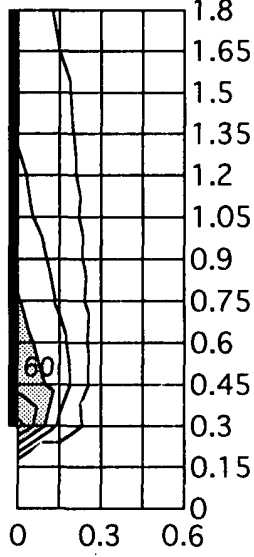

(f) 横長開口 $0.6(\mathrm{~B}) \times 0.3(\mathrm{H})(\mathrm{m})$ $Q_{D}=3.7(\mathrm{~kW})$

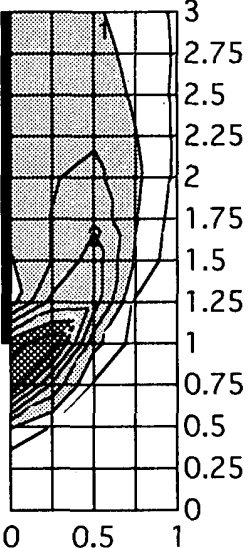

(b) 正方形開口

(a) 綎長開口

$0.1(\mathrm{~B}) \times 0.2(\mathrm{H})(\mathrm{m})$ $\mathrm{Q}_{\mathrm{D}}=2.2(\mathrm{~kW})$

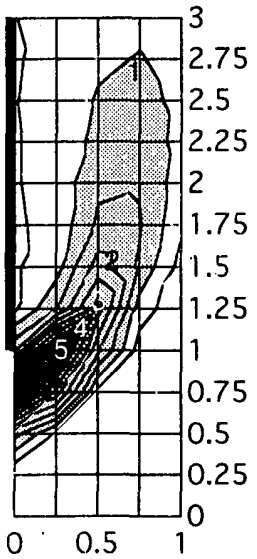

(d) 綖長開口 $0.3(\mathrm{~B}) \times 0.6(\mathrm{H})(\mathrm{m})$ $Q_{0}=5.6(\mathrm{~kW})$

$$
\text { Q }
$$$$
0.2(\mathrm{~B}) \times 0.2(\mathrm{H})(\mathrm{m})
$$$$
Q_{D}=2.3(\mathrm{~kW})
$$$$
\text { パン径 }(0.2(\mathrm{~m})) \text { ・庇無し }
$$$$
\text { 小規模実験 }
$$
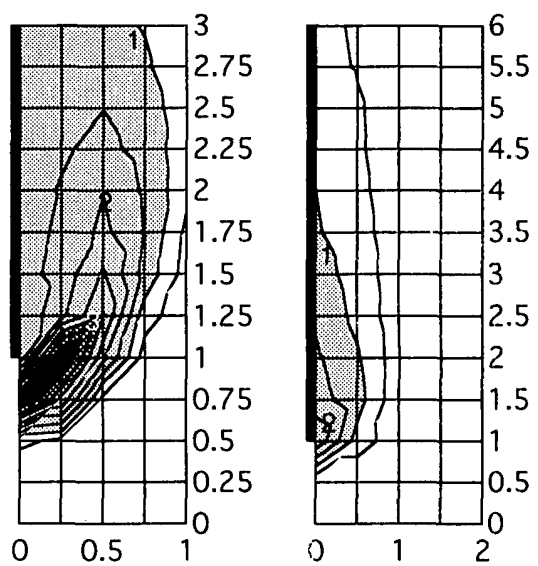

(e) 正方形開口 $0.6(\mathrm{~B}) \times 0.6(\mathrm{H})(\mathrm{m})$ $Q_{D}=4.9(\mathrm{~kW})$

(f) 横長開口 $0.6(\mathrm{~B}) \times 0.3(\mathrm{H})(\mathrm{m})$ $\mathrm{Q}_{\mathrm{D}}=3.7(\mathrm{~kW})$ パン径 $(0.3(\mathrm{~m}))$ ・庇無し 中規模実験

図5 開口噴出気流無次元温度分布（等温線：0.5(-)間隔）
（2）庇を設置した場合

図6は、小規模及び中規模実験の長い庇（区画と同じ幅の庇）を 設置した条件における開口噴出気流の等温度分布 $\Delta T(x, y)$ を開口形 状別に示した一例である。ただし、庇の条件以外は図4に例示した 実験条件と同じである。なお、横長開口の場合に2つの庇の間隔が 小さくなっているのは、庇間の無次元距離（開口高さに対する庇の 距離）の比を他のものと同一にしたためである。

図7はそれぞれ、図6に示した実験結果を式(4)により無次元化し た無次元温度の空間分布 $\Theta(\xi, \eta)$ で示したものである。

庇が存在することにより開口噴出気流の形状は庇の無い場合とは 暴なるが、同一の開口形状に执ける小規模及び中規模実験それでれ
の無次元温度分布は互いに良く一致している。よって、庇が設置き れている場合においても、開口噴出気流の無次元温度 $\Theta$ の分布は開 口及び庇の幾何学的な形状のみに依存すると言える。

\section{3 開口噴出気流と庇の関係}

以上により、開口噴出気流の無次元温度は寸法や熱量に関係な く、形状のみで定まることが知られたので、以下では小規模実験の 結果加庇の効果を考察してみる。

図8流、小規模実験の各開口形状における実験結果老式(4)により 無次元化した無次元温度の空間分布 $\Theta(\xi, \eta)$ を庇の設置条件別に示 しだ例である。ただし、図はパン径 $0.2(\mathrm{~m})$ の実験データを例示し たものである。 


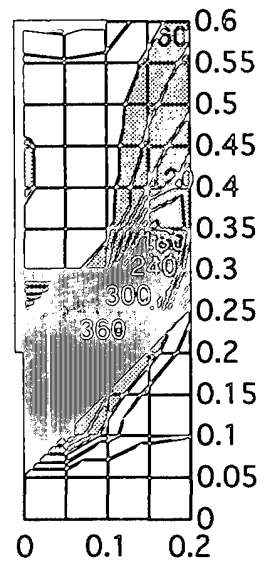

(a) 经長開口

$0.1(\mathrm{~B}) \times 0.2(\mathrm{H})(\mathrm{m})$ $\mathrm{O}_{\mathrm{D}}=2.1(\mathrm{~kW})$

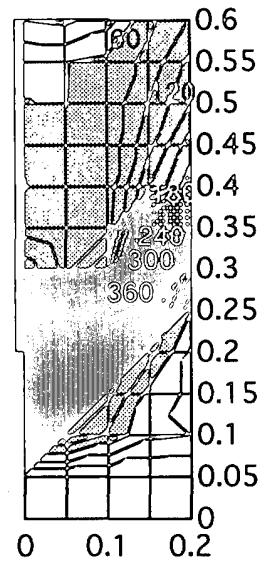

(b) 正方形開口

$0.2(\mathrm{~B}) \times 0.2(\mathrm{H})(\mathrm{m})$ $\mathrm{Q}_{D}=5.1(\mathrm{~kW})$ パン径 $(0.2(\mathrm{~m}))$ ・長い底 小規㷬寄驗

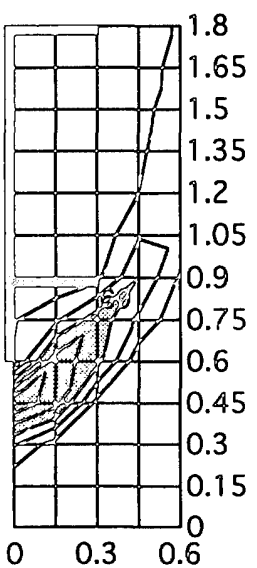

(d) 纷長開口

$0.3(\mathrm{~B}) \times 0.6(\mathrm{H})(\mathrm{m})$ $\mathrm{O}_{\mathrm{D}}=4.2(\mathrm{~kW})$

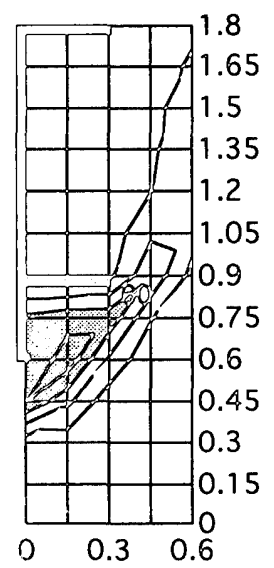

(e) 正方形開口

$0.6(\mathrm{~B}) \times 0.6(\mathrm{H})(\mathrm{m})$

$$
\mathrm{Q}_{0}=6.8(\mathrm{~kW})
$$

パン径 $(0.3(\mathrm{~m}))$ ・長い庇 中規㷬宗驗

图6 開口鉬出氞流温度分布（等温線：20(K)間隔）

横井によれば、開口が縦長の場合は、庇を設置しても開口噴出気 流の気流軸上の温度の変化はほとんどなく、庇を設置したことによ る効果は少ないと言われるが1)、図8(a)〜(c)からも気流軸付近の温 度に関しては確かにその傾向は見られる。しかし、延焼防止上重要 な外壁近傍の温度分布に着目するば、やはり庇設置の効果は出てい ると考えられる。しかも、長い庇の方が効果はより顕著である。ま た、図8(a)〜(c)の結果を見ると、もし庇の奥行きが今回の実験のも のより大きくなれば、気流の形状自体も庇のある場合と無い場合で かなり異なったものになるように思える。一方、正方形開口の図8

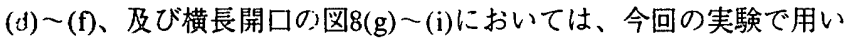
た庇の奥行きでも庇を設置したことにより、明らかに開口噴出気流

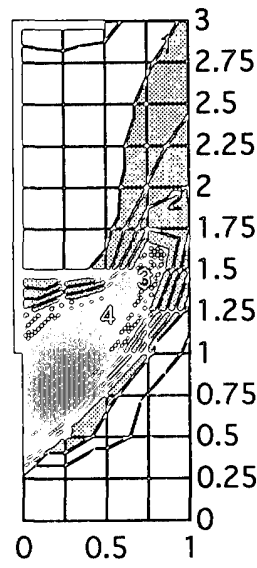

(a) 说辰開口

$0.1(\mathrm{~B}) \times 0.2(\mathrm{H})(\mathrm{m})$ $\mathrm{Q}_{0}=2.1(\mathrm{~kW})$

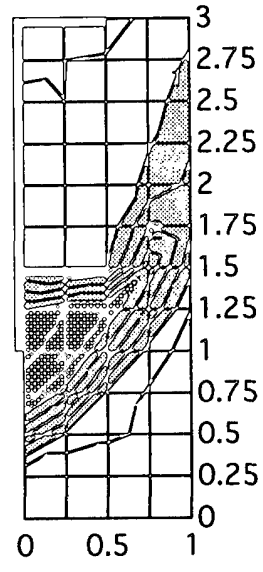

(b) 正方形開口

$0.2(\mathrm{~B}) \times 0.2(\mathrm{H})(\mathrm{cm})$ $\mathrm{Q}_{D}=5.1(\mathrm{~kW})$ パン径 $(0.2(\mathrm{~m}))$ ・長い庇 小規模实験

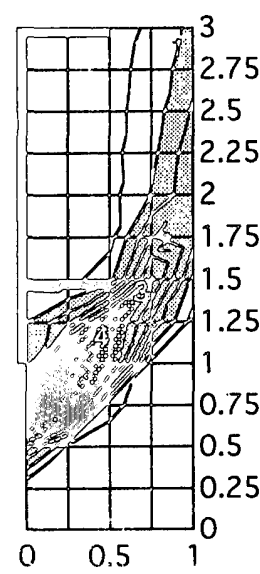

(d) 縦長開回

$0.3(\mathrm{~B}) \times 0.6(\mathrm{H})(\mathrm{m})$

$Q_{D}=4.2(\mathrm{~kW})$

$$
\begin{gathered}
\text { パン径 }(0.3(\mathrm{~m})) \cdot \text { 長い此 } \\
\text { 中規模实䮑 }
\end{gathered}
$$$$
\mathrm{Q}_{\mathrm{D}}=6.8(\mathrm{~kW})
$$

(e) 正方形開口

$0.6(\mathrm{~B}) \times 0.6(\mathrm{H})(\mathrm{m})$

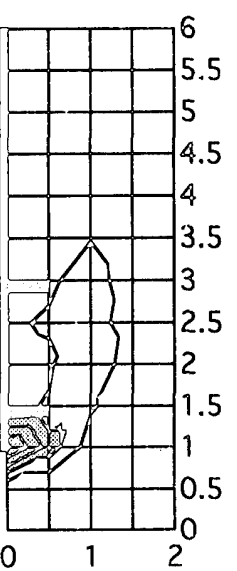

(f) 横長開口

$0.6(\mathrm{~B}) \times 0.3(\mathrm{H})(\mathrm{m})$ $\mathrm{Q}_{\mathrm{D}}=3.0(\mathrm{~kW})$

圆7開口丵出氞流無次元温度分布（等温線：0.5(-)間隔）

軸が壁から離れることがわかる。特に、正方形開口の図8(e)、(f)の 気流温度分布はそれぞれ縦長開口の図8(b)、(c)と類似している。ま た、刎論壁近傍の気流温度も減衰している。さらに、長い庇の方が 短い仳（開[]と同じ幅の庇）を設置した場合より気流軸を壁面から 遠ざける傾问がある。これは、庇を設置した場合は、開口噴出気流 に巻き込まれる空気が庇の上方で外壁側からも供給されるため、絴 長開口の場合と類似した空気巻き込み条件となるためと考えられ る。以上より、上階延焼防止対策として、庇を設置することは常に 有効であると言える。また、特に長い庇の場合は、開口形状の違い による噴出気流の分布形状の差を小さくする働きがあると考えられ る。 


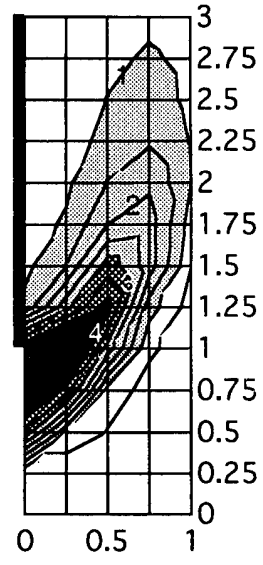

(a) 訨無し

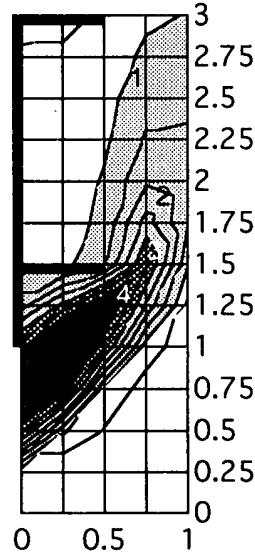

(b) 短い庇

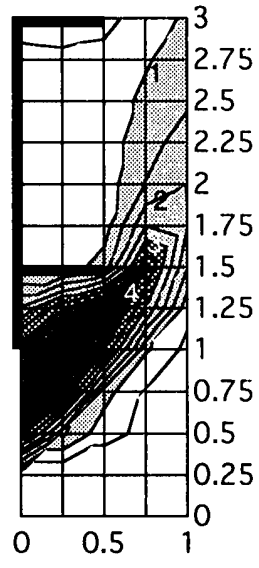

(c) 長い庇

$Q_{D}=1.8(\mathrm{~kW}) \quad Q_{D}=2.1(\mathrm{~kW})$

綎長開口 $(0.1(\mathrm{~B}) \times 0.2(\mathrm{H})(\mathrm{m}))$ ・パン径 $(0.2(\mathrm{~m}))$

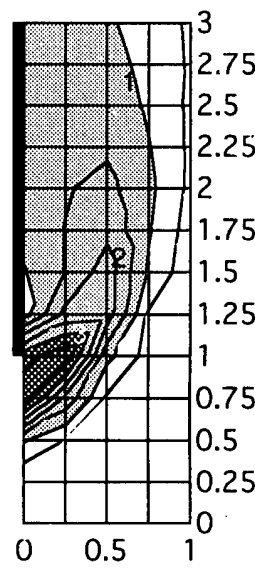

(d) 庇無

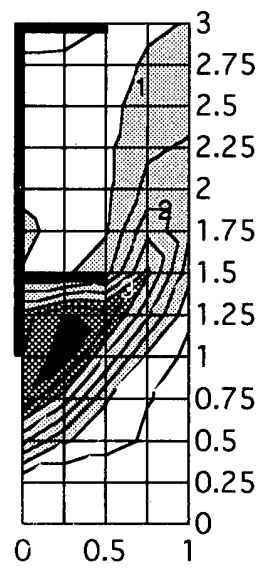

(e)短い庇

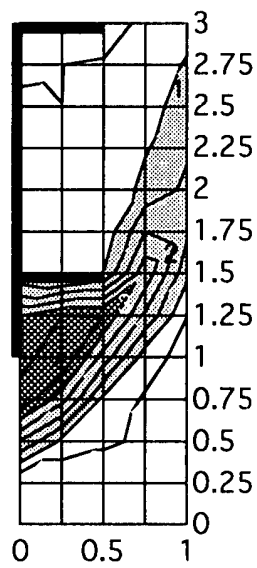

(f) 長い庇

$Q_{D}=2.3(\mathrm{~kW})$

正方形開口

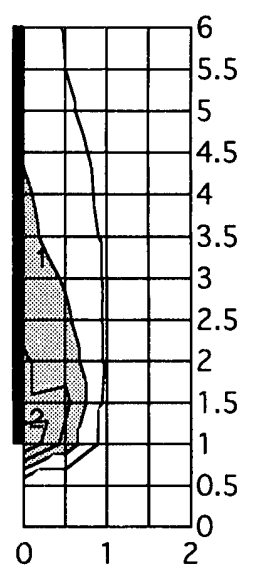

(g) 庇無 $\downarrow$

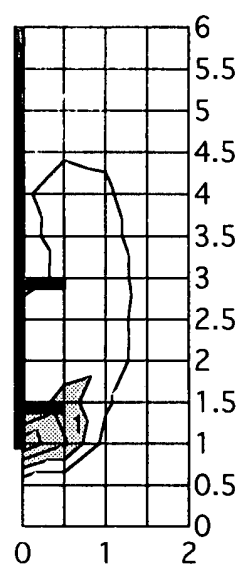

(h) 短い庇

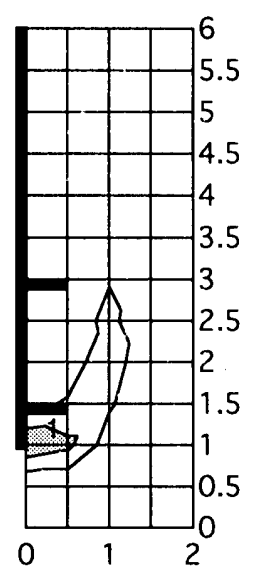

(i) 長い践
5. まとめ

本研究では、開口形状、バルコニー等の設計的要素が上階延焼防 止に果たす効果を評価する手法を開発することを目的として、開口 噴出気流の温度性状を模型実験により調べた。

実験は式(4)の開口噴出気流の無次元温度が、気流軸上のみなら ず、上階ガラス面の近傍を含む気流全体の温度に対して、開口噴出 気流の熱量、模型寸法に関わらない相似則を与えるのか否かを調べ るために、スケールの異なる2つの模型を使って行った。その結果 以下のことが明らかになった。

(1)開[1噴出気流の気流軸を含む全ての領域において、式(4)で定義 される無次元温度 $\Theta$ の分布は、寸法、温度に関わらず、また庇の 設置の有無に関わらず、開口及び庇の幾何学的形状のみに依存す る。すなわち、幾何学的に相似な模型実験の結果に基ついて実大 スウールの，噴出気流の温度を予測することが可能である。

(2)庇在設置することは上階延焼防止上常に有効である。また特に、 庇の奥行きが同じ場合には幅の広い庇ほどその効果は大きくな る。

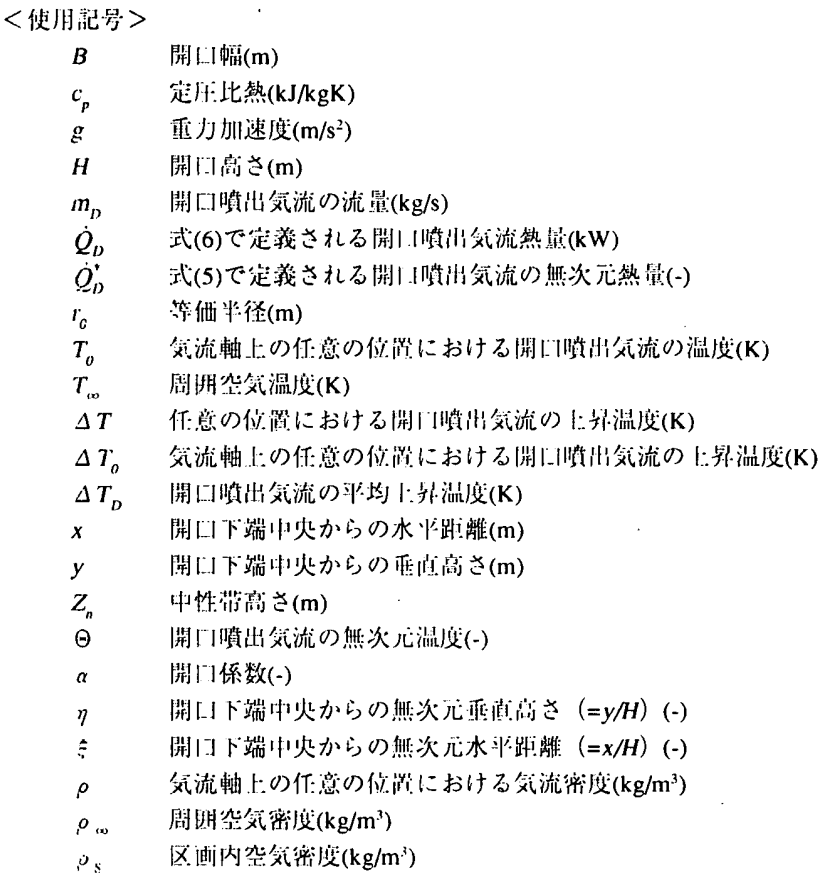

<參考文献〉

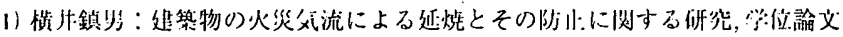

2) L.Y.Cooper, M.Harkeroad, J.Quintiere, W.Rinkinen : An Experimental Study of Upper Hot Layer Stratification in Full-Scale Multiroom Fire Scenarios, Joumal of Heat Transfer, Vol.104, pp.741-749, 1982.11

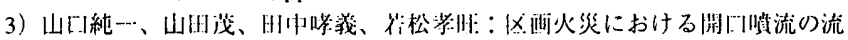

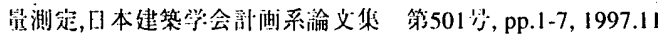

（1997年11月 10 日原稿受理，1998年 6 月 10 日採用決定）

横長開口 $(0.2(\mathrm{~B}) \times 0.1(\mathrm{H})(\mathrm{m}))$ ・ パン径 $(0.2(\mathrm{~m}))$

図8 開口噴出気流無次元温度分布（等温線：0.5(-)間隔） 